Agro-Science Journal of Tropical Agriculture, Food, Environment and Extension Volume 12 Number 1 January 2013 pp 1 - 9

TSSN1119-7455

\title{
COMPARATIVE DEMAND ANALYSIS FOR RICE IN EDO, DELTA AND LAGOS STATES OF NIGERIA
}

\author{
Ojogho, O. and Alufohai, G. O \\ Department of Agricultural Economics, University of Benin, Edo State, Nigeria \\ E-mail: igomercy@yahoo.com
}

\begin{abstract}
The study examined the comparative demand analysis for rice types in Edo, Delta and Lagos states of Nigeria. A multi-stage sampling procedure, involving four stages, was used to select eight hundred and twelve (812) households. Data collected were analysed using both descriptive and inferential statistics. The results of the descriptive statistics showed that the expenditure share of rice was highest in urban Edo (0.25), followed by urban Delta (0.23) and least in urban Lagos (0.22). The quantity consumed was highest in urban Lagos (32.5Kg), followed by urban Delta $(29.3 \mathrm{Kg}$ ) and closely followed by urban Edo (28.4Kg). Higher consumption of rice was by the male-headed households in urban Delta, Lagos and Edo in particular. The result of the inferential statistics showed that urban Edo had the least subsistent level (0.015) while rural Delta had the highest (0.135) for every $\$ 1$ price of rice and $\$ 1$ income of a rice-consuming household. The contribution of the effect of the price of rice on the budget share of rice in the study area was highest in rural Edo (12.1\%) and urban Edo (13.9\%). Edo state is also remarkable as the rice budget share of households decreased by $12.8 \%$ and $15.2 \%$ in rural and urban centres of the state respectively for aone percent increase in the price of rice in the urban centre of the study area unlike the increased contribution of rural Lagos (10.0\%) and rural Delta (15.7\%).
\end{abstract}

Keywords: Expenditure, income rice demand, urban and rural centres, Southwest Nigeria.

\section{INTRODUCTION}

Rice is consumed regularly in Nigerian urban and rural areas. It is a sustainable food for Nigeria, consumed in different forms such as white rice and stew, pudding and rice and onion stew (Ojogho and Alufohai, 2010). Its demand in Nigeria has been increasing since the mid1970 (Awe, 2006; and Daramola, 2005). During the 1960's, Nigeria had a per capita annual rice consumption of $3 \mathrm{~kg}$ which increased to an average of $18 \mathrm{~kg}$ during the 1980's, reaching 22 $\mathrm{kg}$ in the latter half of the 1990's (FAO 2002, and Akpokodje, et al., 2001). Since the mid1980's, rice consumption has increased at an average annual rate of $11 \%$ with only $3 \%$ explained by population growth. Also, within the decade of the 1990's, Erenstien et al (2003) reported a $14 \%$ annual increase in the demand for rice in Nigeria. With total annual rice production at about 2 million metric tons, it is the fourth largest cereal crop grown in the country behind sorghum, millet and maize (Babafada, 2003). However, since Nigeria also imports more than 3 million metric tons of rice, total national consumption exceeds 5 million metric tons per year, or more than $30 \mathrm{~kg}$ per capita per annum. The demand for parboiled rice forced the government to commit a staggering
\#600 million in foreign exchange to milled rice import in 1985. Akpokodje et al (2001) found out that whereas Nigeria spent only about US $\$ 100,000$ on rice importation in 1970 , the value of rice imports has risen to US\$259 million by 1999 . They further averred that between 1961 and 1999, Nigeria spent US\$4 billion. This sudden demand-supply gap of the Nigerian rice economy is not far from the result of Ojogho and Alufohai (2010) in which rice was averred to be among the Nigerian main staples constituting the largest share of the households' total food expenditure, in both rural and urban centres in southern Nigeria in general. However, the share of rice, income and price elasticities of rice were not particular to the rural and urban centres of the three states. This raises a number of pertinent questions both in the policy circle and amongst researchers. What is the average per capita rice consumption in both rural and urban centre in the three states; what is the expenditure share of rice; what is the subsistence level for rice; and what is the demand function for rice in the rural and urban centres of the three states of Nigeria? To answer these questions, the study, therefore, undertook a comparative demand analysis for rice in Edo, 
Delta and Lagos states of Nigeria. To achieve this, the study examined the socio-economic characteristics of respondents, average income and expenditure share of rice, rice meals consumption patterns, and demand function for rice in the study area.

\section{MATERIALS AND METHOD}

The study was carried out in Edo, Delta and Lagos states in the South-western agroecological zone of Nigeria. Administratively, the three states are divided into 68 Blocks (Local Government Areas) with 18 in Edo, 25 in Delta and 25 in Lagos state, and each state has three Senatorial Districts. The location was specifically chosen for its high rice consumption in Nigeria. The three states being among the states in Nigeria with an average percentage rice share of $8 \%-12 \%$ (accounting for about 34\% of the total consumption) in food expenditure (IRRI, 2004), and rain-fed upland, rain-fed lowland and mangrove swamp production systems exist According to the 2006 census (www.nigerianstat.gov.ng), the three states have a population of 16330257 representing $11.7 \%$ of the nation's population, who individually consumes about $24.6 \mathrm{Kg}$ of rice annually (IRRI, 2004). In addition, there are high economic activities in the region which are reflected in the living conditions of the people of the region in comparison with those in Northern Nigeria (Adamu 2003). Besides Agriculture as the predominant occupation of the people in the region, it is a commercial centre with many industries and hotels for the comfort of visitors. It is the nation's nerve centre with over 2000 industries, and $65 \%$ of the county's activities are carried out in the region. In this study, two Local Government Aras were chosen from sach of the three states as follows: Egor and Oredo in Edo state, Ethiope-East and Sapele in Delta state, and Lagos Island and Surulere in Lagos state. The target population for the study was the set of households that consume rice, either the local exsisting types or the imported rice types, in the study area.

Both primary and secondary data were used to generate information for the study. The secondary data were obtained from, among other sources, the National Bureau of Statistics (Federal Office of Statistics), Central Bank of Nigeria, World Bank Report, Journals, Agricultural Development Programme Offices (ADP), Research Institutes, Universities and Government Parastatals. The primary data were collected with the use of a well-structured questionnaire for information on quantity consumed of rice, income of households, total expenditure, and cost of consumed/purchased. rice Data were also collected on the demographic variables, such as age, education level, household size, sex, location (rural or urban which include slums and Government Reservation Areas GRAs), age of members, and other socioeconomic characteristics of households.

A multi-stage sampling procedure, involving four stages, was used in the study to select households within the study area in the three states. The first stage involved a Simple Random Sampling of one Senatorial district from each state using the lucky-dip approach. In this approach, every element of the population is represented by, say, different colours of the same object concealed in a container. The researcher draws one out at random, so that every draw represents the element in question. This gives every element of the population an equal chance of being selected.. The second stage involved a Simple Random Sampling of two (2) Blocks (L.G.As) from the senatorial district using the lucky-dip approach. The Third stage involved a Simple Random Sampling of three Cells in each Block using the lucky-dip approach. As a last stage, a list of all the households in the study area was obtained from the National Population Commission. This list was based on the Enumeration Areas (EA) used for 2006 census purposes. A Simple Random Sampling of 50 rice-consuming households, using the random number table, in each Cell from the list of the enumeration areas (EAs) developed for the 2006 population census by National Population Commission as the sample frame for each Block, making up a total of 300 households from each state. To achieve this last stage, a pilot questionnaire was created to specifically target the study area population. Participants were asked to name the foods frequently served/consumed in their homes. Based on the participants' responses, a list of ten foods commonly served/consumed was generated. If six or more participants reported having been served/consumed a particular food, it was selected to be used in the final questionnaire. However, only households which had rice among the food served were finally sampled. The study, therefore, used a sample size of nine hundred (900) households. However, only eight hundred and twelve (812) copies of questionnaire were retrieved from the respondents making a response rate of $90.2 \%$

Data collected were analysed using both descriptive and inferential statistics. The descriptive statistics used were frequency counts and percentages, while the inferential statistics employed the multiple regression analysis to estimate the complete demand functions for rice types in the study area using the Linear Approximate Almost Ideal Demand System (LA/AIDS) of Deaton and Muellbauer (1980). 
This application follows the work of Dhar and Foltz (2005). Here, total rice expenditures are separable from all other expenditures even

$$
\begin{aligned}
\omega_{2}=\alpha_{21} & +\gamma_{21} \ln p_{1}+\gamma_{22} \ln p_{2}+\gamma_{23} \ln p_{3}+\gamma_{24} \ln p_{4}+\gamma_{25} \ln p_{5}+\gamma_{26} \ln p_{6}+\gamma_{27} \ln p_{7} \\
& +\gamma_{28} \ln p_{8}+\gamma_{29} \ln p_{9}+\beta_{2} \operatorname{In}\left(\frac{X}{P}\right)
\end{aligned}
$$$$
\omega_{3}=\alpha_{31}+\gamma_{31} \ln p_{1}+\gamma_{32} \ln p_{2}+\gamma_{33} \ln p_{3}+\gamma_{34} \ln p_{4}+\gamma_{35} \ln p_{5}+\gamma_{36} \ln p_{6}+\gamma_{37} \ln p_{7}
$$$$
+\gamma_{38} \ln p_{8}+\gamma_{39} \ln p_{9}+\beta_{3} \operatorname{In}\left(\frac{X}{P}\right)
$$$$
\omega_{4}=\alpha_{41}+\gamma_{41} \ln p_{1}+\gamma_{42} \ln p_{2}+\gamma_{43} \ln p_{3}+\gamma_{44} \ln p_{4}+\gamma_{45} \ln p_{5}+\gamma_{46} \ln p_{6}+\gamma_{47} \ln p_{7}
$$$$
+\gamma_{48} \ln p_{8}+\gamma_{49} \ln p_{9}+\beta_{4} \ln \left(\frac{X}{P}\right)
$$$$
\omega_{5}=\alpha_{51}+\gamma_{51} \ln p_{1}+\gamma_{52} \ln p_{2}+\gamma_{53} \ln p_{3}+\gamma_{54} \ln p_{4}+\gamma_{55} \ln p_{5}+\gamma_{56} \ln p_{6}+\gamma_{57} \ln p_{7}
$$$$
+\gamma_{58} \ln p_{8}+\gamma_{59} \ln p_{9}+\beta_{5} \operatorname{In}\left(\frac{X}{P}\right)
$$$$
\omega_{6}=\alpha_{61}+\gamma_{61} \ln p_{1}+\gamma_{62} \ln p_{2}+\gamma_{63} \ln p_{3}+\gamma_{64} \ln p_{4}+\gamma_{65} \ln p_{5}+\gamma_{66} \ln p_{6}+\gamma_{67} \ln p_{7}
$$$$
+\gamma_{68} \ln p_{8}+\gamma_{69} \ln p_{9}+\beta_{6} \operatorname{In}\left(\frac{X}{P}\right)
$$$$
\omega_{7}=\alpha_{71}+\gamma_{71} \ln p_{1}+\gamma_{72} \ln p_{2}+\gamma_{73} \ln p_{3}+\gamma_{74} \ln p_{4}+\gamma_{75} \ln p_{5}+\gamma_{76} \ln p_{6}+\gamma_{77} \ln p_{7}
$$$$
+\gamma_{78} \ln p_{8}+\gamma_{79} \ln p_{9}+\beta_{7} \ln \left(\frac{X}{P}\right)
$$$$
\omega_{8}=\alpha_{81}+\gamma_{81} \ln p_{1}+\gamma_{82} \ln p_{2}+\gamma_{83} \ln p_{3}+\gamma_{84} \ln p_{4}+\gamma_{85} \ln p_{5}+\gamma_{86} \ln p_{6}+\gamma_{87} \ln p_{7}
$$$$
+\gamma_{88} \ln p_{8}+\gamma_{89} \ln p_{9}+\beta_{8} \operatorname{In}\left(\frac{X}{P}\right)
$$

Where $\omega_{\mathrm{i}}$ is the budget share of rice in food expenditure in the $i^{\text {th }}$ state, $\mathrm{X}$ total expenditure on rice, $\mathrm{P}_{1}$ is the price of rice in the entire sample, $\mathrm{P}_{2}$ is the price of rice in the rural centre of the entire sample, $\mathrm{P}_{3}$ is the price of rice in the urban centre of the entire sample, $\mathrm{P}_{4}$ is the price of rice in the rural centre of Lagos, $\mathrm{P}_{5}$ is the price of rice in the urban centre of Lagos, $\mathrm{P}_{6}$ is the price of rice in the rural centre of Delta, $\mathrm{P}_{7}$ is the price of rice in the urban centre of Delta, $\mathrm{P}_{8}$ is the price of rice in the rural centre of Edo, $\mathrm{P}_{9}$ is the price of rice in the urban centre of Edo and $\mathrm{P}$ is the price index defined as

$$
\ln p=\sum_{i=1}^{n} \omega_{i} \ln p_{i}
$$

where $p_{i}$ is the price of the $i^{\text {th }}$ type of rice. within the categories of rice, which can be substitutes or complements, in Nigeria. The model, in budget share form, is given as

The income (expenditure) and price elasticities were computed using the following equations

Income elasticity, $\eta_{i}=1+\frac{\beta_{i}}{\omega_{i}}$

Own-price elasticity, $\epsilon_{i i}=-1+\frac{\gamma_{i}}{\omega_{i}}-\beta_{i}$ [4]

Cross-price elasticity, $\epsilon_{i j}=\frac{\gamma_{i j}}{\omega_{i}^{i}}-\frac{\beta_{i}}{\omega_{i}} \omega_{j}$

\section{RESULTS AND DISCUSSION \\ Socio-economic Characteristics of \\ Respondents}

The distribution of households according to the socio-economic characteristics of households is shown in Table 1. The results showed that Lagos state had the largest proportion $(91.7 \%)$ of maleheaded households followed by Edo state $(89.7 \%)$ and least in Delta state $(86.3 \%)$. Among the male-headed households of the urban respondents, 158 or $55.4 \%, 151(57.4 \%)$, and $147(55.7 \%)$ were respectively in the urban centres of Delta, Edo and Lagos states. With Delta state having the largest proportion $(13.7 \%)$, Edo state had the largest proportion (4.9\%) of urban female-headed households while urban Delta had the least proportion $(3.5 \%)$. Among the rural female-headed households, rural Delta had the largest proportion $(10.2 \%)$ while the least proportion (3.8\%) lived in rural Lagos. This suggests a higher consumption of rice by the male-headed households in urban Delta, Lagos and Edo in particular and Lagos state in general. This consumption is higher in both urban and rural Delta for the male-headed households and female-headed households than in other areas of the study area, but more in urban Edo for the female-headed households. The study area had a younger population who were mainly children and teenagers with a large proportion of them in the urban centres than rural centres. Among the states, urban Edo had the largest proportion $(40.7 \%)$ of children, but the least proportion $(20.7 \%)$ in among the rural centres while rural Delta had the largest proportion (24.2\%) of children and least proportion $(37.9 \%)$ in the urban centres. A higher proportion $(16.3 \%)$ of the teenagers were in urban Edo than urban Delta $(10.2 \%)$ while more $(8.7 \%)$ of the group were in rural Lagos. 
Table 1: Summary Statistics of Socio-economic Characteristics of Households

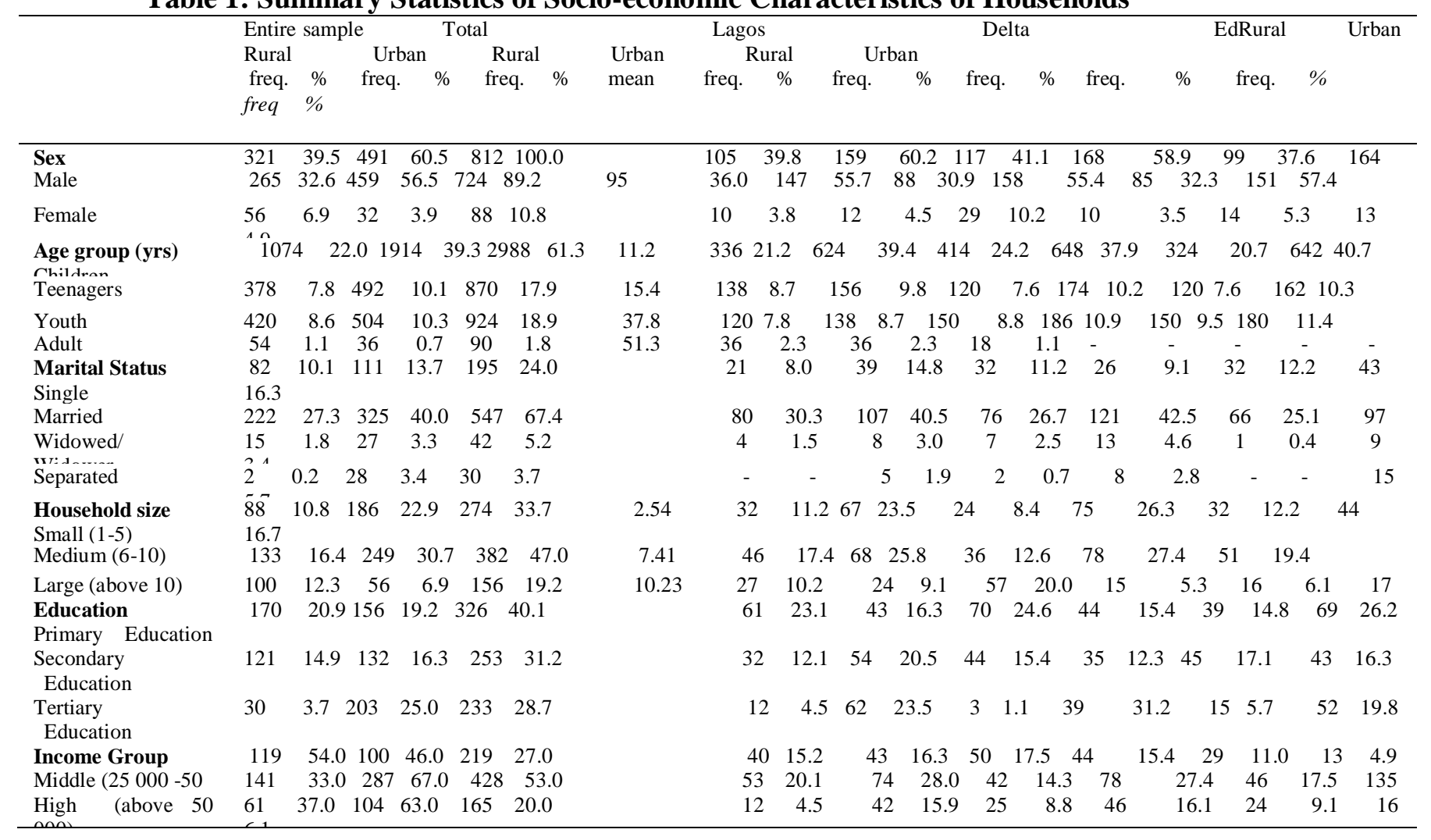

There were more rice-consuming youth in urban Edo $(11.4 \%)$ and Delta $(10.9 \%)$ than in urban Lagos $(8.7 \%)$ while there were more riceconsuming adults in urban Lagos $(2.3 \%)$ and Delta $(1.1 \%)$ than in urban Edo which had none in the study area. Rice consumption/demand is mostly among the married $(67.4 \%)$ and is higher in the urban centre than the rural of the study area. Among the married, 197 (69.1\%) of them lived in Delta state, $187(70.8 \%)$ in Lagos state and 163 or $62 \%$ in Edo state while a largest proportion of them lived in the urban Delta (42.5\%) and least proportion $(25.1 \%)$ in rural Edo. The proportion of widows/widowers was smaller in the rural areas than the urban centres accounting for only $5.2 \%$ in the sample. However, the proportion of widow/widower was highest in the urban Delta (31.0\%). Rice consumption is likely to increase among widows/widowers in the state in particular and the study area at large if the proportion of this group increases. A very small proportion of separated $(3.7 \%)$, with $3.4 \%$ and $0.2 \%$ of them lived respectively in the urban and rural centres. Half of this group (50\%) contributed to rice demand in urban Edo. Among the single riceconsuming household heads, the urban centres of the region had more of them (111 or 13.7\%) than rural centres ( 82 or $10.1 \%$ ) with urban $(16.3 \%)$ and rural $(12.2 \%)$ Edo having the largest proportions while urban Delta $(9.1 \%)$ and rural Lagos had the least proportions.

The mean household size was 3,8 and 10 for the small-, medium- and large-household sizes, respectively. However, the sample had a mediumsize household range that lived in the urban centres of the study area. This distribution by household size was also shared by the three states in the study area. The distribution among the medium-size households is highest in Edo state with $58.6 \%$ of the respondents, particularly in urban Edo (39.2\%) and least in rural Delta (12.6\%) when compared with rural Lagos. It not only implied that rice consumption is mainly among the urban population but that it's largely among the mediumsize households. However, large-size households also consume rice but the consumption is largely in rural areas. The large-size households were found mainly in Delta state (25.3\%), particularly in rural Delta $(20.0 \%)$ while the least proportion of the large-size rice-consuming households resided in Edo state (12.5\%) with more of them in the urban $(6.5 \%)$ than the rural $(6.1 \%)$ centres of the state. It means that as household size increased, 
rice consumption/demand shifted from urban to rural.

The Education level distribution of household heads shows that more $(40.1 \%)$ of the respondents had primary education with Edo State respondents contributing the highest $(41.1 \%)$ to the number and Lagos state, the least (39.4\%). This category was more $(20.9 \%)$ in the rural areas with the highest contribution $(24.6 \%)$ in rural Delta and the least in rural Edo (14.8\%). Among the secondary education category, households in Edo state $(33.5 \%)$ had the highest proportion of rice consumers, followed by households in Lagos $(32.6 \%)$ while Delta state had the least proportion $(27.7 \%)$. Households with tertiary education had the least proportion $(28.7 \%)$ with more contribution from urban Delta $(31.2 \%)$ and rural Edo (25.5\%). Also more of the urban dwellers $(25.0 \%)$ in the study area had tertiary education, and only $4 \%$ in the rural areas had tertiary education. Among these respondents, more of them were in the Delta $(31.2 \%)$, and the least in Edo (19.8\%). This suggests that rice consumption was more prominent among the tertiary-education household heads and mainly in the urban centres. This increase was more in urban Delta than in the other states.

It showed that over half $(53 \%)$ of the household heads were in the middle income class and were mainly concentrated $(67 \%)$ in the urban centres of the study area while only $20 \%$ of them are high income earners with $63 \%$ of this high income earners were in the urban centres. While respondents (households) from Edo State had the highest percentage $(68.8 \%)$ of household heads in middle-income class and respondents from Delta
State had the highest proportion $(33.0 \%)$ of lowincome class who were mainly rural dwellers, the general trend was that the proportion of riceconsuming households decreased as they move from the middle-income class to high-income class. This decrease was most noticed in Edo state $(68.8 \%-15.2 \%)$, particularly in urban Edo $(51.3 \%$ - $6.1 \%$ ) and least noticed in Delta state $(42.1 \%$ $24.9 \%)$, particularly in urban Delta $(27.4 \%$ $16.1 \%$ ). This decrease is probably due to the effects of economies of scale since households will buy rice in bulk as income increases. Also, as income increased, consumption shifted from high in rural to high in urban centres of the study area.

\section{Average Income, Expenditure Share of Rice and Quantity of Rice Consumed}

Table 2 shows the average income, expenditure share of rice and quantity of rice consumed. Delta state had the highest mean income of $\$ 16945$ in rural centres and $\$ 48326$ in urban centres of the state, followed by Lagos state with $\$ 16308$ in rural and $\$ 47148$ in urban and least in Edo state $\$ 15125$ in rural centre and $\$ 46952$ in urban centres of the state. The expenditure share of rice was highest in urban Edo (0.25), followed by urban Delta (0.23) and least in urban Lagos (0.22). Among the rural dwellers, Delta state had the highest (0.21) and least in Edo (0.19). This suggests that rice is important in the 'food basket' of the urban Edo dwellers, though with the least mean income. The mean annual quantity of rice consumed was $32.0 \mathrm{Kg}$ per capita represented by $36.3 \mathrm{Kg}$ in the urban centres and $25.8 \mathrm{Kg}$ in the rural centres of the study area.

Table2: Average Income and Expenditure Share of Rice

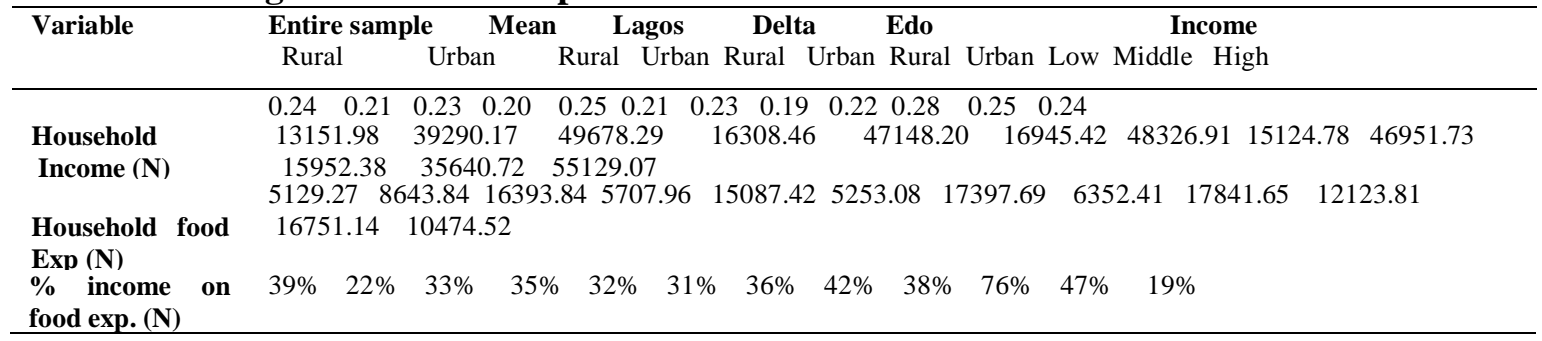


The quantity consumed was highest in urban Lagos $(32.5 \mathrm{Kg})$, followed by urban Delta $(29.3 \mathrm{Kg})$ and closely followed by urban Edo $(28.4 \mathrm{Kg})$. Among the rural dwellers, rice consumers in rural Delta had the highest per capita $(33.1 \mathrm{Kg})$ and least in rural Edo $(23.4 \mathrm{Kg})$.

\section{Rice Meals Consumption Patterns}

Table 3 shows the rice meals consumption patterns. Rice was more consumed as white rice and stew with consumers more in Delta state, while rice cake had the lowest percentage (3\%) consumer among the respondents who were more in Lagos. Among the white rice and stew consumers, about half $(43.3 \%)$ of the respondents are low-income earners while only $9.4 \%$ of them were in the high-income group. However, the rice cake consumers were mainly high-income earners $(87.5 \%)$ with very small proportion of the middleincome group. A high percentage $(62.3 \%)$ of the middle-income group was among the white rice and onion stew consumers, 9.4\% among the highincome group, representing $20.1 \%$ and $7.9 \%$, respectively of the middle- and high-income in the study area. Among this group, more consumers were found in Lagos (19.7\%), followed by rice consumers in Delta $(16.1 \%)$ and then rice consumers in Edo (15.2\%). The high-income group respondents consumed rice in a more 'expensive' form such as fried rice (18.8\%) and braised rice $(18.2 \%)$ besides rice cake $(12.7 \%)$ and curry rice $(10.9 \%)$. With $27 \%$ of the respondents as low-income earners, rice was mainly consumed as white rice and stew, and white rice and onion stew giving a composite percentage of $51.6 \%$. None of the low-income earners consumed rice cake.

\section{Demand Function for Rice in the Study Area}

Table 4 shows the estimated parameters and associated asymptotic errors of the LA/AIDS models for rice in the study area. The demand system has only fifty-four (54) free parameters consisting of nine (9) independent $\alpha$ 's, nine (9) independent $\beta$ 's and thirty-six (36) independent $\gamma$ 's. Majority of the $\gamma_{i j}$ were negative which implied that rice consumption in the area complemented rice consumption anywhere else in the study area. Thus, households can buy rice for consumption outside their rural and urban residential areas. For example, a unit per cent increase in the price of rice increased overall rice budget share by $30.3 \%$ in the area, and reduce overall rice budget share by $18.5 \%$ and $21.2 \%$ in the rural and urban centres respectively. Similarly, one per cent increase in the price of rice in the rural area reduced rice budget share by $29.0 \%$ while a similar per cent increase in urban areas increased rice budget share by $19.9 \%$. Among the states, urban Edo had the least subsistent level (0.015) while rural Delta had the highest (0.135) for every $\$ 1$ price of rice and $\$ 1$ income of a riceconsuming household. The contribution of the effect of the price of rice on the budget share of rice in the study area was highest in rural Edo $(12.1 \%)$ and urban Edo (13.9\%), followed rural Lagos (10.5\%), and least in rural Delta (4.7\%). Edo state is also remarkable as rice budget share of households decreased by $12.8 \%$ and $15.2 \%$ in rural and urban centres of the state respectively for a per cent increase in the price of rice in the urban centre of the study area unlike the increased contribution of rural Lagos $(10.0 \%)$ and rural Delta $(15.7 \%)$. Rice was price inelastic (positive price effect) in the study area, and was highest in rural Edo (0.122), followed by urban Delta (0.117) and least in rural Lagos (0.105).

Majority of the $\beta$ 's were statistically significant, but negative, which indicated that the budget shares were responsive to real total food expenditure with real income held constant. Unit per cent increase in the total food expenditure decreased budget share of rice by $0.041 \%$ in the sample and $0.03 \%$ in the urban area but by $0.002 \%$ in the rural areas. The negative signs for rice, except in rural Delta, indicate that rice is a necessity. The policy implication is that a subsidy to the price of rice, as advocated by policy makers, may improve household rice consumption further, and worsen the demand-supply gap. This will also have a higher drain on the Nigeria foreign exchange 
Table 3: Rice Meals demand Pattern of Respondents

\begin{tabular}{|c|c|c|c|c|c|c|c|c|c|c|c|c|c|c|c|c|c|c|c|}
\hline \multirow[t]{3}{*}{ Rice Meals } & \multicolumn{4}{|c|}{ Entire sample } & \multicolumn{2}{|c|}{ Total } & \multicolumn{2}{|c|}{ Lagos } & \multicolumn{2}{|c|}{ Delta } & \multirow{2}{*}{\multicolumn{3}{|c|}{ Edo }} & \multicolumn{5}{|c|}{ Income } & \\
\hline & \multicolumn{2}{|c|}{ Rural } & \multicolumn{2}{|c|}{ urban } & \multirow[b]{2}{*}{ freq. } & \multirow{2}{*}{\multicolumn{2}{|c|}{$\%$ freq. }} & \multirow[b]{2}{*}{$\%$ fr } & \multirow{2}{*}{ req. } & \multirow[b]{2}{*}{$\%$ fr } & & & & \multirow{2}{*}{$\begin{array}{r}\text { low } \\
\%\end{array}$} & \multicolumn{3}{|c|}{ middle } & high & \\
\hline & Freq. & $\%$ & freq. & $\%$ & & & & & & & freq. & \multicolumn{2}{|c|}{ freq. } & & $\%$ & freq. & $\%$ & eq. & $\%$ \\
\hline $\begin{array}{l}\text { White Rice } \\
\text { and onion stew }\end{array}$ & 22 & 6.9 & 116 & 23.6 & 138 & 17.0 & 52 & 19.7 & 46 & 16.1 & 40 & 15.2 & & 39 & 17.8 & 86 & 20.1 & 13 & 7.9 \\
\hline Rice cake & - & - & 24 & 4.9 & 24 & 3.0 & 12 & 4.5 & 8 & 2.8 & 4 & 1.5 & & - & - & 3 & 7.0 & 21 & 12.7 \\
\hline Rice pudding & 69 & 21.4 & 37 & 7.5 & $5 \quad 106$ & 13.1 & 28 & 10.6 & 40 & 14.0 & 38 & 14.4 & & 25 & 11.4 & 65 & 15.2 & 16 & 9.716 .1 \\
\hline Curry Rice & - & - & 41 & 8.3 & 41 & 5.0 & 13 & 4.9 & 11 & 3.9 & 17 & 6.5 & & 10 & 4.6 & 13 & 3.0 & 18 & 10.9 \\
\hline Fried Rice & 13 & 4.2 & 68 & 13.8 & 81 & 10.0 & 40 & 15.2 & 14 & 4.9 & 27 & 10.3 & & 15 & 6.8 & 35 & 8.2 & 31 & 18.8 \\
\hline Braised Rice & 7 & 2.2 & 66 & 13.4 & 73 & 9.0 & 15 & 5.7 & 25 & 8.8 & 33 & 12.5 & & 10 & 4.6 & 33 & 7.7 & 30 & 1.8 \\
\hline Jollof Rice & 48 & 15.4 & 41 & 8.4 & 89 & 11.0 & 31 & 11.7 & 26 & 9.1 & 32 & 12.2 & & 20 & 9.1 & 58 & 13.6 & 11 & 6.7 \\
\hline $\begin{array}{l}\text { White Rice } \\
\text { and Stew }\end{array}$ & 102 & 32.7 & 69 & 14.1 & 171 & 21.1 & 44 & 16.7 & 67 & 23.5 & 60 & 22.8 & & 74 & 33.8 & 81 & 18.9 & 16 & 9.7 \\
\hline Coconut Rice & 23 & 7.4 & 9 & 1.8 & 32 & 3.9 & 11 & 4.2 & 12 & 4.2 & 9 & 3.4 & & 5 & 2.3 & 21 & 4.9 & 6 & 3.6 \\
\hline Banga Rice & 37 & 11.8 & 20 & 4.1 & 57 & 7.0 & 18 & 6.8 & 36 & 12.6 & 3 & 1.1 & & 21 & 9.6 & 33 & 7.7 & 3 & 1.8 \\
\hline
\end{tabular}

Table 4: Estimated Parameters and Associated Asymptotic Errors of the LA/AIDS Models for Rice

\begin{tabular}{|c|c|c|c|c|c|c|c|c|c|}
\hline \multirow[t]{2}{*}{ Parameter } & \multicolumn{3}{|c|}{ Entire sample } & \multicolumn{2}{|r|}{ Lagos } & \multicolumn{2}{|c|}{ Delta } & \multicolumn{2}{|c|}{ Edo } \\
\hline & $i=1$ & $\begin{array}{l}\text { Rural } \\
i=2\end{array}$ & $\begin{array}{l}\text { Urban } \\
i=3\end{array}$ & $\begin{array}{c}\text { Rural } \\
i=4\end{array}$ & $\begin{array}{c}\text { urban } \\
i=5\end{array}$ & $\begin{array}{c}\text { rural } \\
i=6\end{array}$ & $\begin{array}{c}\text { urban } \\
i=7\end{array}$ & $\begin{array}{c}\text { rural } \\
i=8\end{array}$ & $\begin{array}{c}\text { urban } \\
i=9\end{array}$ \\
\hline$\alpha_{\mathrm{i}}$ & $\begin{array}{c}0.213 \\
(0.0119)\end{array}$ & $\begin{array}{c}0.101 \\
(0.0130)\end{array}$ & $\begin{array}{c}0.121 \\
(0.0081)\end{array}$ & $\begin{array}{c}0.102 \\
(0.0170)\end{array}$ & $\begin{array}{c}0.122 \\
(0.0108)\end{array}$ & $\begin{array}{c}0.135 \\
(0.0087)\end{array}$ & $\begin{array}{r}0.100 \\
(0.0035)\end{array}$ & $\begin{array}{c}0.091 \\
(0.0158)\end{array}$ & $\begin{array}{r}0.015 \\
(0.0157)\end{array}$ \\
\hline$\gamma_{1 \mathrm{i}}$ & 0.303 & -0.185 & -0.212 & 0.105 & -0.064 & $\begin{array}{c}-0.047 \\
-0.09)\end{array}$ & 0.117 & 0.122 & -0.139 \\
\hline$\gamma_{2 \mathrm{i}}$ & $\begin{array}{c}-0.185 \\
(0.0930)\end{array}$ & $\begin{array}{c}0.290 \\
(0.0029)\end{array}$ & $\begin{array}{c}0.199 \\
(0.0190)\end{array}$ & $\begin{array}{c}-0.106 \\
(0.0102)\end{array}$ & $\begin{array}{l}-0.131 \\
(0.0513)\end{array}$ & $\begin{array}{c}0.233 \\
(0.1163)\end{array}$ & $\begin{array}{r}-0.268 \\
(0.0257)\end{array}$ & $\begin{array}{c}0.170 \\
(0.0925)\end{array}$ & $\begin{array}{r}-0.202 \\
(0.0412)\end{array}$ \\
\hline$\gamma_{3 \mathrm{i}}$ & -0.212 & 0.199 & 0.320 & 0.100 & -0.111 & 0.157 & -0.173 & -0.128 & -0.152 \\
\hline$\gamma_{4 i}$ & $\begin{array}{c}0.105 \\
(0.0501)\end{array}$ & $\begin{array}{c}-0.106 \\
(0.0102)\end{array}$ & $\begin{array}{c}0.100 \\
(0.0014)\end{array}$ & $\begin{array}{c}0.300 \\
(0.0200)\end{array}$ & $\begin{array}{l}-0.190 \\
(0.0150)\end{array}$ & $\begin{array}{r}-0.149 \\
(0.0114)\end{array}$ & $\begin{array}{c}-0.156 \\
(0.0101)\end{array}$ & $\begin{array}{r}-0.104 \\
(0.0143)\end{array}$ & $\begin{array}{r}0.200 \\
(0.0601)\end{array}$ \\
\hline$\gamma_{5 \mathrm{i}}$ & -0.064 & -0.131 & -0.111 & -0.190 & 0.002 & 0.175 & 0.109 & 0.130 & 0.062 \\
\hline$\gamma_{6 \mathrm{i}}$ & $\begin{array}{c}(0.0115) \\
-0.047 \\
(0.0109)\end{array}$ & $\begin{array}{c}(0.0513) \\
0.233 \\
(0.1163)\end{array}$ & $\begin{array}{c}(0.0018) \\
0.157 \\
(0.0198)\end{array}$ & $\begin{array}{c}(0.0150) \\
-0.149 \\
(0.0114)\end{array}$ & $\begin{array}{l}(0.0204) \\
0.175 \\
(0.0061)\end{array}$ & $\begin{array}{c}(0.0061) \\
-0.243 \\
(0.0103)\end{array}$ & $\begin{array}{r}(0.0054) \\
0.008 \\
(0.0119)\end{array}$ & $\begin{array}{c}(0.0126) \\
0.014 \\
(0.0174)\end{array}$ & $\begin{array}{r}(0.0342) \\
-0.148 \\
(0.0512)\end{array}$ \\
\hline$\gamma_{7 \mathrm{i}}$ & $\begin{array}{c}(0.0117) \\
0.117 \\
(0.0125)\end{array}$ & $\begin{array}{l}(0.1103) \\
-0.268 \\
(0.0257)\end{array}$ & $\begin{array}{c}(0.0198) \\
-0.173 \\
(0.0265)\end{array}$ & $\begin{array}{c}-0.156 \\
(0.0101)\end{array}$ & $\begin{array}{l}(0.0001) \\
0.109 \\
(0.0054)\end{array}$ & $\begin{array}{c}(0.0105) \\
0.008 \\
(0.0119)\end{array}$ & $\begin{array}{r}(0.0119) \\
0.369 \\
(0.0061)\end{array}$ & $\begin{array}{c}(0.01 / 4) \\
0.114 \\
(0.0128)\end{array}$ & $\begin{array}{r}(0.0512) \\
-0.120 \\
(0.0121)\end{array}$ \\
\hline$\gamma_{8 \mathrm{i}}$ & $\begin{array}{c}0.122 \\
(0.0131)\end{array}$ & $\begin{array}{c}0.170 \\
(0.0925)\end{array}$ & $\begin{array}{l}-0.128 \\
(0.0379)\end{array}$ & $\begin{array}{c}-0.104 \\
(0.0143)\end{array}$ & $\begin{array}{l}0.130 \\
(0.0126)\end{array}$ & $\begin{array}{c}0.014 \\
(0.0174)\end{array}$ & $\begin{array}{c}0.114 \\
(0.0128)\end{array}$ & $\begin{array}{c}-0.441 \\
(0.0013)\end{array}$ & $\begin{array}{r}0.123 \\
(0.0127)\end{array}$ \\
\hline$\gamma_{9 \mathrm{i}}$ & $\begin{array}{c}-0.139 \\
(0.0121)\end{array}$ & $\begin{array}{l}-0.202 \\
(0.0412)\end{array}$ & $\begin{array}{l}-0.152 \\
\quad(0.0212)\end{array}$ & 2) & $\begin{array}{c}0.062 \\
0.0601)\end{array}$ & $\begin{array}{r}-0.148 \\
(0.0342)\end{array}$ & $\begin{array}{r}-0.120 \\
(0.0512)\end{array}$ & $\begin{array}{c}0.123 \\
(0.0121)\end{array}$ & $\begin{array}{r}0.376 \\
(0.0127)\end{array}$ \\
\hline$\beta_{\mathrm{i}}$ & $\begin{array}{l}-0.041 \\
(0.0200)\end{array}$ & $\begin{array}{l}-0.002 \\
\quad(0.0010)\end{array}$ & $\begin{array}{l}-0.030 \\
\quad(0.0120)\end{array}$ & $0)^{-0.011}$ & $\begin{array}{l}-0.015 \\
0.0049)\end{array}$ & $\begin{array}{c}0.122 \\
(0.0070)\end{array}$ & $\begin{array}{r}-0.013 \\
(0.2450)\end{array}$ & $\begin{array}{c}-0.009 \\
(0.0035)\end{array}$ & $\begin{array}{r}-0.001 \\
(0.0039)\end{array}$ \\
\hline
\end{tabular}


Table 5: Expenditure and Price Elasticities for Rice in Rural and Urban centres of the States

\begin{tabular}{|c|c|c|c|c|c|c|}
\hline \multirow[t]{3}{*}{ Parameters } & \multicolumn{6}{|c|}{ Price Elasticities } \\
\hline & \multicolumn{2}{|c|}{ Lagos state } & \multicolumn{2}{|c|}{ Delta state } & \multicolumn{2}{|c|}{ Edo state } \\
\hline & Rural & Urban & Rural & Urban & Rural & Urban \\
\hline$\epsilon_{1 i}$ & 0.511 & -0.938 & -0.733 & -0.767 & -0.510 & 1.012 \\
\hline$\epsilon_{2 i}$ & & -0.977 & 0.713 & 0.450 & 0.531 & 0.261 \\
\hline$\epsilon_{3 i}$ & & & -2.279 & -0.084 & -0.044 & -0.833 \\
\hline$\epsilon_{4 i}$ & & & & 0.617 & 0.506 & -0.509 \\
\hline$\epsilon_{5 i}$ & & & & & -3.154 & 0.658 \\
\hline$\epsilon_{6 i}$ & & & & & & 0.710 \\
\hline Expenditure Elasticity $\left(\boldsymbol{\eta}_{i}\right)$ & 0.945 & 0.940 & 1.581 & 0.943 & 0.953 & 0.995 \\
\hline
\end{tabular}

\section{Expenditure and Price Elasticities for Rice in Rural and Urban Centres of the States}

Table 5 shows the expenditure and price elasticities for rice in rural and urban centre of the three states. The results showed that price elasticities for rice differd across the states These differences tend to be large, and most of the elasticities were positive in the three states. Table 5 shows that the expenditure (income) elasticities of rice in rural and urban areas of Lagos state were 0.945 and 0.940 , respectively. In rural and urban areas of Delta state, the expenditure elasticities were 1.581 and 0.963 , respectively while they were 0.953 and 0.995 , respectively in rural and urban areas of Edo state. The results showed that rice in the three states is a siaple food commodity. However, while it is a necessity in urban Delta, and rural and urban areas of Lagos and Edo state, it is a luxury in rural areas of Delta state. This may imply that rice is still highly prized in rural areas of Delta state.

The Table also shows that the own-price elasticities of rice in rural areas of Lagos and urban centres of Delta and Edo states were 0.571, 0.617 and 0.710 , respectively. This implies that rice is giffen food commodity in these areas. The ownprice elasticities of rice in urban Lagos, and rural Delta and Edo were -0.977, -2.279 and -3.154 respectively. These imply that rice price increases during the lean season in these areas. As a consequence, these areas are the most at risk as the price of rice fluctuates.

The cross-price elasticities of demand between the brands of rice in rural and urban Lagos was the least (-0.938) while the cross-price elasticity between brands of rice in rural Lagos and urban Edo was the highest (1.012). However, except for the positive cross-price elasticity between rice demand in rural Lagos and urban Edo (1.012), the cross-price elasticities between rice demand in rural Lagos and the other centres were negative. This implies that the available brands of rice in rural Lagos and urban Edo, be they local or imported, are close substitute while the same rice in rural Lagos and other centre in the study area are complements which implies that they are prepared and consumed together. Contrarily, the brands of rice in urban Lagos are all substitutes with those in other centre of the study area.

\section{CONCLUSION}

The study showed that there were more riceconsuming households in the urban centres than rural with the highest proportion in Edo state by mainly children, teenagers and youth, and least proportion in Delta. Rural Edo state is also remarkable in this study with a higher price effect, higher own-price inelasticity and highest crossprice elasticity compared with the other centres among the three states in the study area. Besides policies targeted toward increased rice production and productivity to narrow the demand-supply gap in these states, income-oriented policies will have a greater effect on rice consumption than price related policies particularly in Edo state. 


\section{REFERENCE}

Adamu FL (2003). Globalisation and Economic Localization in Northern Nigeria. A paper presented at the Development Studies Associations annual conference on globalisation and development, Scotland, 9th - 12th September, 2003.

Akpokodje G, Lancon F, Erenstein O (2001). Nigeria's Rice Economy: State of the rt. The Nigeria Rice in a Competitive World: Constraints, Opportunities and strategic choices .Final Report Presented to West Africa Rice Development Association (WARDA), ouake, Cote'Ivoire. Pp: 55

Awe O (2006). Ban on Rice Importation Depresses Global Trade, Punch 3.

Babafada M (2003). Integrated Rice Production and Export in Nigeria. Paper presented at a Seminar on Sustainable rice production in Nigeria" organized by central bank of Nigeria held at hamadala hotel kaduna from January 14$15,1-4$

Daramola B (2005). Government Policy and Competitiveness of Nigerian Rice Economy. Paper presented at the 'Workshop on Rice Policy and Food Security in Sub-Saharan Africa' organized by WARDA, Cotonou, Republic of Benin, November $7^{\text {th }}$ $9^{\text {th }}$.
Deaton A, Muellbaur J (1980). An Almost Ideal Demand System. Amer. Eco. Rev, 70: 312 $-326$.

Dhar T, Foltz J.D (2005). "Milk by any other name ... consumer benefits from labelled milk." Amer. J. Agricultural Economics, 87:214-228.

Erenstien O, Lancon F, Osiname O, Kebbeh M (2003). Operational Sing the Strategic Framework for Rice Sector Revitalization in Nigeria, in: the Nigerian Rice Economy in a Competitive World, constraints, opportunities and strategic choices: West Africa Rice Development Association (WARDA). The Africa Rice Centre, Abidjan, Cted Ivoire: 38pp

Food and Agriculture Organization (2002). African Development Indicator. FAO, Rome.

International Rice Research Institute (2004). World Rice Statistics.

Ojogho O, Alufohai GO (2010). Impact of Price and Total Expenditure on Food Demand in South-Western Nigeria. Afr. J. Food, Agriculture, Nutrition and Development, 10 (11): 4350-4363.

Ojogho O, Alufohai GO (2010). Rice Consumption Pattern in Nigeria: A Road to Sustainable food Consumption. Int'l. $J$. Agriculture, 3(3): 56-63 